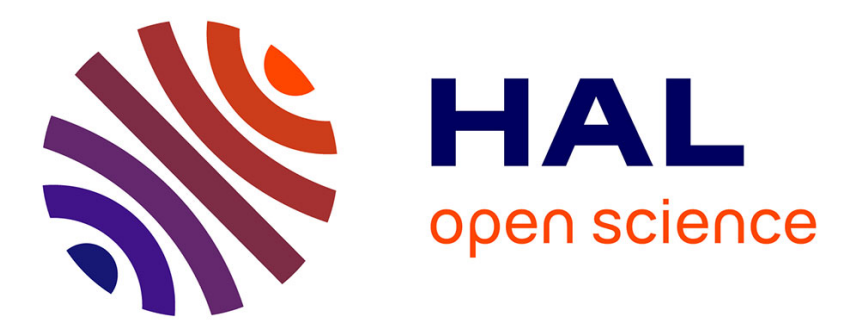

\title{
Does Muscular Power Predict Bone Mineral Density in Young Adults?
}

\author{
Anthony Khawaja, Patchina Sabbagh, Jacques Prioux, Gautier Zunquin, \\ Georges Baquet, Ghassan Maalouf, Rawad El Hage
}

\section{To cite this version:}

Anthony Khawaja, Patchina Sabbagh, Jacques Prioux, Gautier Zunquin, Georges Baquet, et al.. Does Muscular Power Predict Bone Mineral Density in Young Adults?. Journal of Clinical Densitometry, 2019, 22 (3), pp.311-320. 10.1016/j.jocd.2019.01.005 . hal-02055752

HAL Id: hal-02055752

https://hal-univ-rennes1.archives-ouvertes.fr/hal-02055752

Submitted on 13 Mar 2019

HAL is a multi-disciplinary open access archive for the deposit and dissemination of scientific research documents, whether they are published or not. The documents may come from teaching and research institutions in France or abroad, or from public or private research centers.
L'archive ouverte pluridisciplinaire HAL, est destinée au dépôt et à la diffusion de documents scientifiques de niveau recherche, publiés ou non, émanant des établissements d'enseignement et de recherche français ou étrangers, des laboratoires publics ou privés. 


\section{Does Muscular Power Predict Bone Mineral Density in Young Adults?}

\section{Article type: Original research manuscript}

Anthony Khawaja ${ }^{1,2}$, Patchina Sabbagh ${ }^{1,3}$, Jacques Prioux ${ }^{2}$, Gautier Zunquin ${ }^{4}$, Georges

Baquet $^{3}$, Ghassan Maalouf ${ }^{5}$, Rawad El Hage ${ }^{1}$

1. Department of Physical Education, FAS, University of Balamand, Kelhat El Koura, Lebanon.

2. Movement, Sport, and Health Sciences Laboratory (M2S), UFR-STAPS, University of Rennes 2, Rennes, France.

3. Unité de Recherche Pluridisciplinaire Sport, Santé, Société (URePSSS-EA 7369), Lille University, Ronchin, France.

4. Unité de Recherche Pluridisciplinaire Sport, Santé, Société (URePSSS-EA 7369), University of the Littoral Opal Coast, Dunkerque, France.

5. Bellevue University Medical Center, Faculty of Medicine, Saint Joseph University, Mansourieh, Lebanon.

Corresponding author: Rawad El Hage

E-mail address: rawadelhage21@hotmail.com

Tel.: 00961/3/713605

Fax: 00961/6/930278

Department of Physical Education

Faculty of Arts and Sciences, University of Balamand, P.O. Box 100 Tripoli, Lebanon. 


\section{Abstract}

The aim of this study was to explore the relationships between maximum power and bone variables in a group of young adults. Two hundred and one young adults (53 men and 148 women) whose ages range from 18 to 35 years voluntarily participated in this study. Weight and height were measured, and body mass index (BMI) was calculated. Body composition, bone mineral content $(B M C)$ and bone mineral density (BMD) were determined for each individual by Dual-energy X-ray absorptiometry (DXA). Vertical jump was evaluated using a validated field test (Sargent test). The highest vertical jump was selected. Maximum power ( $P$ max, in watts) of the lower limbs was calculated accordingly. In young men, maximum power was positively correlated to whole body (WB) BMC $(r=0.65 ; p<0.001)$, WB BMD $(r=$ 0.41; $p<0.01)$, L1-L4 BMC $(r=0.54 ; p<0.001)$, total hip (TH) BMC $(r=0.50 ; p<0.001)$, femoral neck (FN) BMC ( $r=0.35 ; p<0.01)$, FN cross-sectional area (CSA) $(r=0.33 ; p<0.05)$ and FN cross-sectional moment of inertia (CSMI) ( $r=0.50 ; p<0.001)$. In young women, maximum power was positively correlated to WB BMC $(r=0.48 ; p<0.001)$, WB BMD $(r=$ 0.28; $p<0.001)$, L1-L4 BMC $(r=0.34 ; p<0.001)$, TH BMC $(r=0.43 ; p<0.001)$, TH BMD $(r=$ $0.21 ; p<0.01)$, FN BMC $(r=0.42 ; p<0.001)$, FN BMD $(r=0.31 ; p<0.001)$, FN CSA $(r=0.41 ; p$ $<0.001)$, FN CSMI $(r=0.40 ; p<0.001)$ and FN Z ( $r=0.41 ; p<0.01)$. The current study suggests that maximum power is a positive determinant of WB BMC, WB BMD, FN CSA and FN CSMI in young men. It also shows that maximum power is a positive determinant of WB $B M C, W B B M D, T H B M D, F N ~ B M D, F N C S A, F N C S M I$ and FN $Z$ in young women.

Keywords: Maximum power; DXA variables; Young adults. 


\section{Introduction}

Ageing leads to a reduction in lean mass (LM) and bone mineral density (BMD) and an alteration of bone quality (1). The World Health Organization (WHO) defined osteoporosis as a systemic skeletal disease characterized by low bone mass and micro-architectural deterioration of bone tissue, leading to an increased bone fragility and susceptibility to fracture risk (1-3). Osteopenia and osteoporosis represent an important health problem of the ending $20^{\text {th }}$ and the beginning $21^{\text {st }}$ century (1). Hip fractures alone are expected to reach 6.3 million per year globally by 2050 (2).

Exercise-based interventions are an interesting alternative to medication due to their low cost and their safety (fewer serious side effects), and additional health benefits including improved balance and fall reduction. Furthermore, because osteoporotic fractures happen most frequently at the hip and spine, site-specificinterventions to increase BMD are highly desirable. Targeted strengthening of the hip and spine using specific resistance exercises is useful since sufficient skeletal loading stimulates net bone formation at the solicited skeletal sites. A recent meta-analysis recommends the use of multi-component exercises for osteoporotic individuals to improve bone health outcomes (4). Exercise that exerts in high muscular contraction or ground-reaction forces on the skeleton, such as resistance training or structured jump-training, respectively, increase BMD in pre- and post-menopausal women (4).

The regular practice of physical activities characterized by significant mechanical stresses stimulates bone formation and improves BMD in the most solicited sites (5-10). Indeed, according to Frost theory (11) "the mechanostat", the resistance of the bone adapts to the mechanical stresses applied to it. This theory has been supported by numerous studies on 
animals $(12,13)$. In humans, it has been shown that body weight and LM are the best determinants of BMD in both sexes $(14,15)$.

Many studies showed that high cardiorespiratory fitness and muscle strength are correlated with higher BMD values at the proximal femur, distal tibia and fibula, lumbar spine and total hip (16-18). Although, it is widely accepted that muscle strength is significantly correlated with bone mass, little is known about the relationship between maximum power and BMD. Indeed, muscle mass and bone mass are closely related throughout life, and previous studies have documented the associations of $\mathrm{LM}$ with bone mineral content (BMC) and BMD $(19,20)$. A positive relationship between bone mass and anaerobic power is reported in professional jumpers (21). On the other side, LM as well as anaerobic power are considered as the best predictors of bone mass during growth (22-25).

Several studies have shown a significant correlation between BMD and the performances obtained in some physical tests used in current sports practice (26-29). A previous study found that vertical jump, maximum power of the lower limbs, and 1-RM half-squat are positively correlated with bone variables in overweight and obese adult women (30).

However, the relationship between maximum power and bone variables needs to be more clarified. Therefore, the purpose of this study was to investigate the relationships between maximum power and bone variables in a group of young adults. We hypothesized that maximum power would be significantly associated with bone variables in both sexes. Identification of new determinants of BMC, BMD and hip geometric indices in young adults, would allow screening and early management of future cases of osteopenia and osteoporosis.

\section{Materials and Methods}




\section{Subjects and Study Design}

Two hundred and one young adults whose ages ranged from 18 to 35 years voluntarily participated in the present study. They were divided into two groups: 53 young men and 148 young women. All participants were nonsmokers and had no history of major orthopedic problems or other disorders known to affect bone metabolism or physical tests of the study. Pregnant women, amenorrheic, and those taking medications that may affect bone and calcium metabolism (corticosteroid or anticonvulsant therapy) were excluded from the study. All participants completed an interview about medical history including menstrual history and medication use. The work described has been carried out in accordance with the declaration of Helsinki (regarding human experimentation developed for the medical community by the World Medical Association). Other inclusion criteria included no diagnosis of comorbidities and no history of fracture. An informed written consent was obtained from the participants. The current study was approved by the University of Balamand Ethics Committee.

\section{Anthropometrics}

Height (in centimeters) was measured in the upright position to the nearest $1 \mathrm{~mm}$ with a standard stadiometer. Body weight (in kilograms) was measured on a mechanic scale with a precision of $100 \mathrm{~g}$. Subjects were weighed wearing only underclothes. Body mass index (BMI) was calculated as body weight divided by height squared (in kilograms per square meter) (31). Body composition including LM (Kg) and fat mass (FM; \%, Kg) was evaluated by dual-energy X-ray absorptiometry (DXA; GE Healthcare, Madison, WI).

\section{Bone Variables}


$\mathrm{BMC}$ (in grams) and BMD (in grams per square centimeter) were determined for each individual by DXA at whole body (WB), lumbar spine (L1-L4), total hip (TH), and femoral neck (FN; GE Healthcare). FN cross-sectional area (CSA), strength index (SI), buckling ratio (BR), FN section modulus (Z), cross-sectional moment of inertia (CSMI) and L1-L4 TBS were also evaluated by DXA (32-34). The TBS is derived from the texture of the DXA image and has been shown to be related to bone microarchitecture and fracture risk. The TBS score can assist the healthcare professional in assessing fracture risk $(33,34)$. In our laboratory, the coefficients of variation were less than $1 \%$ for BMC and BMD and less than $3 \%$ for FN CSA $(17,35-37)$. The same certified technician performed all analyses using the same technique for all measurements.

\section{Maximum power}

The vertical jump was evaluated using a field test (Sargent test). Two main parameters were retained: vertical jump performance $(\mathrm{cm})$ and power $(\mathrm{w})$. The subjects performed three jumps with 2 minutes of recovery between jumps. The highest vertical jump was selected. Maximum power (P max, in watts) of the lower limbs was calculated (38). $P \max (w)=v g / 2 *$ body weight $(\mathrm{kg}) * V H * 9.81 ; g$ is equal to 9.81 and $H$ is vertical jump height in meters.

\section{Statistical Analysis}

The means and standard deviations were calculated for all clinical data and for the bone measurements. Intersex differences were specified by Student's t-test. Associations between maximum power and bone variables were given as Pearson correlation coefficients and $r$ values were reported. Multiple linear regression analysis models were used to test the relationship of maximum power and LM with bone variables, and $R^{2}$ values were reported. 
Statistical analyses were performed using the SigmaStat 3.1 Program (Jandel Corp., San Rafael, CA). A level of significance of $p<0.05$ was used.

\section{Results}

\section{Clinical Characteristics and Bone Data of the Study Population}

Mean values of age, weight, height, BMI, LM, FM, FM percentage, bone variables, vertical jump and maximum power are displayed in Table 1. Age, L1-L4 BMD, L1-L4 TBS, BR and FN SI were not significantly different between men and women. Weight, fat mass, height, BMI, LM, WB BMC, WB BMD, L1-L4 BMC, TH BMC, TH BMD, FN BMC, FN BMD, FN CSA, FN CSMI, FN Z, vertical jump and maximum power were significantly higher in men than in women. Fat mass percentage was significantly higher in women compared to men.

\section{Correlations Between Clinical Characteristics and Bone Variables in young men}

Maximum power was positively correlated to WB BMC $(r=0.65 ; p<0.001)$, WB BMD $(r=$ $0.41 ; p<0.01)$, L1-L4 BMC $(r=0.54 ; p<0.001)$, TH BMC $(r=0.50 ; p<0.001)$, FN BMC $(r=$ $0.35 ; p<0.01)$, FN $\operatorname{CSA}(r=0.33 ; p<0.05)$ and FN CSMI $(r=0.50 ; p<0.001)$. Vertical jump was positively correlated to WB BMC $(r=0.31 ; p<0.05)$, L1-L4 BMC $(r=0.40 ; p<0.01)$ and FN CSMI $(r=0.29 ; p<0.05)$. FM was positively correlated to WB BMC $(r=0.29 ; p<0.05)$. FM was negatively correlated to L1-L4 TBS $(r=-0.37 ; p<0.01)$ and FN SI $(r=-0.45 ; p<0.001)$. LM was positively correlated to WB BMC $(r=0.57 ; p<0.001)$, WB BMD $(r=0.42 ; p<0.01)$, L1-L4 BMC $(r=0.27 ; p<0.05)$, TH BMC $(r=0.47 ; p<0.001)$, FN BMC $(r=0.38 ; p<0.01)$, FN CSA $(r$ $=0.40 ; p<0.01)$, FN CSMI $(r=0.52 ; p<0.001)$ and FN Z $(r=0.48 ; p=0.05)$ (Table 2). 


\section{Correlations Between Clinical Characteristics and Bone Variables in young women}

Maximum power was positively correlated to WB BMC $(r=0.48 ; p<0.001)$, WB BMD $(r=$ 0.28; $p<0.001)$, L1-L4 BMC $(r=0.34 ; p<0.001)$, TH BMC $(r=0.43 ; p<0.001)$, TH BMD $(r=$ $0.21 ; p<0.01)$, FN BMC $(r=0.42 ; p<0.001)$, FN BMD $(r=0.31 ; p<0.001)$, FN CSA $(r=0.41 ; p$ $<0.001)$, FN CSMI ( $r=0.40 ; p<0.001)$ and FN Z $(r=0.41 ; p<0.01)$. Vertical jump was positively correlated to FN SI $(r=0.17 ; p<0.05)$. FM was positively correlated to WB BMC ( $r$ $=0.33 ; p<0.001)$, WB BMD $(r=0.39 ; p<0.001)$, L1-L4 BMC $(r=0.17 ; p<0.05)$, L1-L4 TBS $(r=$ 0.18; $p<0.05)$, TH BMC $(r=0.31 ; p<0.001)$, TH BMD $(r=0.27 ; p<0.001)$, FN BMC $(r=0.30$; $p<0.001)$, FN BMD $(r=0.32 ; p<0.001)$, FN CSA $(r=0.34 ; p<0.001)$, FN CSMI $(r=0.25 ; p<$ $0.01)$ and FN Z ( $r=0.44 ; p<0.001)$. FM was negatively correlated to FN SI $(r=-0.33 ; p<$ 0.001). LM was positively correlated to WB BMC $(r=0.79 ; p<0.001)$, WB BMD $(r=0.58 ; p<$ 0.001), L1-L4 BMC ( $r=0.59 ; p<0.001)$, L1-L4 BMD $(r=0.30 ; p<0.001)$, TH BMC $(r=0.75 ; p<$ 0.001), TH BMD $(r=0.45 ; p<0.001)$, FN BMC $(r=0.63 ; p<0.001)$, FN BMD $(r=0.52 ; p<$ 0.001), FN CSA $(r=0.72 ; p<0.001)$, FN CSMI $(r=0.71 ; p<0.001)$ and FN Z $(r=0.73 ; p<$ $0.001)$. LM was negatively correlated to $B R(r=-0.26 ; p<0.05)$ (Table 3$)$.

\section{Multiple Linear Regressions in men}

After adjusting for $L M$, maximum power remained positively correlated to WB BMC ( $p<$ 0.001), L1-L4 BMC $(p<0.001)$, TH BMC $(p=0.013)$ and FN CSMI $(p=0.021)$. Maximum power was a stronger positive determinant of $\mathrm{WB} B M C$ and TH BMC than LM. LM was a stronger positive determinant of FN CSMI than maximum power. After adjusting for maximum power, LM remained positively correlated to WB BMC $(p=0.009)$, TH BMC $(p=0.039)$, FN CSA $(p=$ $0.041)$ and FN CSMI ( $p=0.011)$ (Table 4). 


\section{Multiple Linear Regressions in women}

The correlations between maximum power and bone variables disappeared after adjusting for LM. LM remained positively correlated to WB BMC $(p<0.001)$, WB BMD $(p<0.001)$, L1L4 BMC $(p<0.001)$, L1-L4 BMD $(p<0.001)$, TH BMC $(p<0.001)$, TH BMD $(p<0.001)$, FN BMC $(p<0.001)$, FN BMD $(p<0.001)$, FN CSA $(p<0.001)$, FN CSMI $(p<0.001)$ and FN Z $(p<0.001)$ after adjusting for maximum power. $L M$ remained negatively correlated to $B R(p=0.01)$ after adjusting for maximum power (Table 5).

\section{Discussion}

The present study conducted in a group of young adults mainly shows that maximum power is positively correlated to WB BMC, WB BMD, FN CSA and FN CSMI in young men. This study also shows a positive correlation between maximum power and WB BMC, WB BMD, TH $B M D, F N ~ B M D, F N ~ C S A, F N ~ C S M I$ and FN Z in young women. The strengths of the associations between maximum power and bone variables were poor to moderate in both sexes.

After adjusting for LM, maximum power remained significantly correlated to WB BMC, L1-L4 BMC, TH BMC and FN CSMI in young men, whereas the correlation between maximum power and bone variables disappeared after adjusting for LM in young women. Accordingly, the relationships between maximum power and bone variables in young adults seem to be influenced by gender. These relationships seem to be stronger in men compared to women in our cohort. FM percentage is known to be higher in women compared to men. Our results are consistent with those of two previous studies conducted on young adults. El Khoury et al. (39) showed that maximum power was positively correlated to WB BMC, WB BMD, L1-L4 $B M D, T H B M D$, and $F N Z$ in a group of young overweight and obese men. These correlations 
disappeared after adjusting for LM. Another previous study found a positive correlation between maximum power and BMD in both young women and men (40). A recent study has shown that maximum power is a positive determinant of many bone variables in a group of young overweight and obese women (30).

Our results showed that vertical jump is positively correlated to WB BMC, L1-L4 BMC, and FN CSMI in young men, whereas vertical jump is positively correlated only to FN SI in young women. Accordingly, the relationships between vertical jump and bone variables in young adults seem to be influenced by gender. These relationships seem to be stronger in men compared to women in our cohort. Our results are in accordance with those of a previous study conducted on young adults that has shown that vertical jump was positively correlated to $W B B M C$ and $B M D$ in young women. In contrary, it did not find any correlation between vertical jump and bone variables in young men (40). The relationships between vertical jump performance and bone variables may be influenced by the weight status of the studied population (40). However, a more recent study has shown that vertical jump was the best predictor of TH and FN BMDin a group of young overweight and obese women (30).

The current study shows that, in young men, FM is positively correlated only to WB BMC, whereas FM is negatively correlated to L1-L4 TBS and FN SI. It also shows that, in young women, FM is positively correlated to WB BMC, L1-L4 TBS, WB BMD, TH BMD, FN BMD, FN CSA, FN CSMI and FN Z, whereas FM is negatively correlated to FN SI. Based on our results, the relationships between FM and bone variables are sex-dependent and seem to be stronger in women compared to men. The latter may partially explain the sex-specificity regarding the relationships between vertical jump/maximum power and bone variables obtained in our study. Janicka et al. (41) conducted a study on three hundred healthy 
sexually mature adolescents and young adults (150 men and 150 women) between 13 and 21 years old. They found positive correlations between FM and DXA and computed tomography (CT) bone variables in women, whereas these correlations were weaker or nonexistent in men (41). Accordingly, these authors suggested that adipose tissue is not beneficial to bone structure in young men (41). In line with these results, a recent study conducted on a group of young overweight and obese men did not find any positive correlation between FM and bone variables (39).

The type of FM may differently affect bone tissue. The relation between visceral adipose tissue (VAT) and bone has been previously documented in many studies. A study conducted on young women suggests that VAT was negatively correlated with BMD, while subcutaneous adipose tissue (SAT) was positively correlated with BMD (42). Similarly, another study conducted by Choi et al. (43) showed that VAT was negatively correlated with BMD, while SAT was positively correlated with BMD in Korean men and women, after adjusting for body weight. In addition, Yamaguchi et al. (44) confirmed that SAT was positively correlated with BMD in men with type 2 diabetes.

Our study shows that LM is positively correlated to WB BMC, WB BMD, FN CSA, FN CSMI and FN Z in young men. Regarding women, our results also show that LM is positively correlated to $W B B M C, W B B M D, F N C S A, F N C S M I$ and FN Z. LM remained positively correlated to WB BMC, TH BMC, FN CSA and FN CSMI after adjusting for maximum power in young men, whereas $L M$ remained positively correlated to WB BMC, WB BMD, FN CSA, FN CSMI and FN $\mathrm{Z}$, after adjusting for maximum power in young women. Our results are in accordance with those of many previous studies (18-25). A study conducted on a group of young overweight and obese men found a positive correlation between LM and several bone variables such as 
WB BMC, WB BMD, FN CSA and FN Z (45). Zakhem et al. showed that LM was positively correlated to WB BMC and WB BMD in both young women and men (40). Several previous studies have shown that LM was a strong determinant of bone variables (39, 46-54). Accordingly, LM is a positive determinant of bone variables in young adults and this relation is valid in both sexes. El Hage et al. conducted a study on a group of adolescent girls and boys ( 35 girls and 65 boys). In boys, they showed that LM was strongly correlated to WB BMD and L1-L4 BMD and that FM was not positively correlated to BMD and was negatively correlated to WB bone mineral apparent density. In girls, they found that LM and FM were positively correlated to WB BMD, while only FM was correlated to L1-L4 BMD. They suggested that $L M$ is a strong determinant of $W B B M D$ and $L 1-L 4 B M D$ in boys, and that $F M$ is a stronger determinant of WB BMD than LM in girls (55).

Our study had some limitations. First, the cross-sectional nature of the present study is a limitation because it cannot evaluate the confounding variables. The second limitation is the 2-dimensional nature of DXA $(56,57)$. The third limitation is the low number of subjects especially in the male group. Finally, maximum power was not directly measured but indirectly calculated using a formula after performing a vertical jump test. However, to our knowledge, the present study is one of few studies that aimed at exploring the relationships between maximum power and many bone variables such as $B M D, B M C$, and hip geometric indices in young adults. Vertical jump and maximum power are easily calculated when performing a simple physical test. Interestingly, our results showed that the relationships between maximal power and bone variables in young adults are sex-dependent and seem to be stronger in men compared to women. 
In conclusion, the current study suggests that maximum power is a positive determinant of BMC, WB BMD, FN CSA and FN CSMI in young men. It also suggests that maximum power is a positive determinant of WB BMC, WB BMD, TH BMD, FN BMD, FN CSA, FN CSMI and FN Z in young women. In addition, our study shows that maximum power is an independent determinant of WB BMC and L1-L4 BMC in young men. Our study is one of very few studies that demonstrated positive correlations between maximum power and bone variables in young adults. Thus, implementing strategies to increase maximum power of the lower limbs in young adults may be useful for preventing osteoporosis later in life. Finally, our study may be useful for the prevention and early detection of osteoporosis and osteopenia.

\section{Acknowledgments}

This study was supported by a grant from the research council of the University of Balamand, Lebanon.

\section{Conflict of Interest}

None of the authors reported a conflict of interest related to the study. 


\section{References}

1. Kirchengast S. 2015 Bone Loss and Physical Activity - A Bio Anthropological perspective. J Osteopor Phys Act. 4:1.

2. Cooper C, Campion G, Melton LJ 3rd. 1992 Hip fractures in the elderly: a world-wide projection. Osteoporos Int. 2:285-289.

3. [No authors listed]. 1994. Assessment of fracture risk and its application to screening for postmenopausal osteoporosis. Report of a WHO Study Group. World Health Organ Tech Rep Ser. 843:1-129.

4. Giangregorio LM, Papaioannou A, Macintyre NJ, et al. 2014 Too Fit to Fracture: exercise recommendations for individuals with osteoporosis or osteoporotic vertebral fracture. Osteoporos Int. 25:821-35.

5. Ainsworth BE, Youmans CP. 2002 Tools for physical activity counseling in medical practice. Obes Res. 10 (1):69S-75S.

6. Söderman K, Bergström E, Lorentzon R, Alfredson H. 2000 Bone mass and muscle strength in young female soccer players. Calcif Tissue Int. 67:297-303.

7. Nikander R, Sievänen H, Heinonen A, Kannus P. 2005 Femoral neck structure in adult female athletes subjected to different loading modalities. J Bone Miner Res. 20:520-8.

8. Krustrup P, Hansen PR, Andersen L, et al. 2010 Long-term musculoskeletal and cardiac health effects of recreational football and running for premenopausal women. Scand J Med Sci Sports. 20:58-71. 
9. Ferry B, Duclos M, Burt L, Therre P, Le Gall F, Jaffré C. 2011 Bone geometry and strength adaptations to physical constraints inherent in different sports: comparison between elite female soccer players and swimmers. J Bone Miner Metab. 29:342-51.

10. El Hage R. 2012 Geometric indices of hip bone strength in obese, overweight, and normal-weight adolescent boys. Osteoporos Int. 23 (5):1593-1600.

11. Frost HM. 2003 Bone's mechanostat: a 2003 update. Anat Rec A Discov Mol Cell Evol Biol. 275:1081-101.

12. Hart KJ, Shaw JM, Vajda E, Hegsted M, Miller SC. 2001 Swim-trained rats have greater bone mass, density, strength, and dynamics. J Appl Physiol. 91:1663-8.

13. Warner SE, Shea JE, Miller SC, Shaw JM. 2006 Adaptations in cortical and trabecular bone in response to mechanical loading with and without weight bearing. Calcif Tissue Int. 79:395-403.

14. Petit MA, Beck TJ, Shults J, Zemel BS, Foster BJ, Leonard MB. 2005 Proximal femur bone geometry is appropriately adapted to lean mass in overweight children and adolescents. Bone. 36:568-76.

15. Cobayashi F, Lopes L, Taddei J. 2005 Bone mineral density in overweight and obese adolescents. J Pediatr (Rio J). 81:337-42.

16. Henderson NK, Price RI, Cole JH, Guttedridge DH, Bhagat Cl. 1995 Bone density in young women is associated with body weight and muscle strength but not dietary intakes. J Bone Miner Res. 10:384-393.

17. El Hage R, Zakhem E, Theunynck D, et al. 2014 Maximal oxygen consumption and bone mineral density in a group of young Lebanese adults. J Clin Densitom. 17:320-324. 
18. Vicente-Rodriguez G, Urzanqui A, Mesena SI, et al. 2008 Physical fitness effect on bone mass in mediated by the independent association between lean mass and bone mass through adolescence: a cross-section study. J Bone Miner Metab. 26:288-294.

19. Doyle F, Brown J, Lachance C. 1970 Relation between bone mass and muscle weight. Lancet. 1:391-393.

20. Perez-Gomez J, Rodriguez GV, Ara I, et al. 2008 Role of muscle mass on spirit performance: gender differences? Eur J Appl Physiol. 102:685-694.

21. Haydari M, Rahnama N, Khayambashi K, Marandi M. 2010 Relationship between bone mineral content, bone mineral density and anaerobic power in professional jumpers. Brit J Sport Med. 10.1136/bjsm.2010.078725.13

22. Vicente-Rodriguez G, Jimenez-Ramirez J, Ara I, Serano-Sanchez JA, Dorado C, Cabet JAL. 2003 Enhanced bone mass and physical fitness in prepubescent footballers. Bone. 33:853859.

23. Ara I, Vicente-Rodriguez G, Perez-Gomez J, et al. 2013 Influence of extracurricular sport activities on body composition and physical fitness in boys: a 3-year longitudinal study. Int J Obesity. 30:1062-1071

24. Calbet JAL, Moysi JS, Dorado C, Rodriguez LP. 1998 Bone mineral content and density in professional tennis players. Calcified tissue int. 62:491-496.

25. Witzke KA, Snow CM. 1999 Lean body mass and leg power best predict bone mineral density in adolescent girls. Med Sci Sports Excerc. 31:1558-1563. 
26. Vicente-Rodriguez G, Dorado C, Perez-Gomez J, Gonzalez-Henriquez JJ, Calbet JA. 2004 Enhanced bone mass and physical fitness in young female handball players. Bone. 35:120815.

27. Dixon WG, Lunt M, Pye SR, et al. 2005 Low grip strength is associated with bone mineral density and vertebral fracture in women. Rheumatology (Oxford). 44:642-6.

28. Sirola J, Rikkonen T, Tuppurainen M, Jurvelin JS, Alhava E, Kröger H. 2008 Grip strength may facilitate fracture prediction in perimenopausal women with normal BMD: a 15-year population based study. Calcif Tissue Int. 83:93-100.

29. Sherk VD, Palmer IJ, Bemben MG, Bemben DA. 2009 Relationships between body composition, muscular strength, and bone mineral density in estrogen-deficient postmenopausal women. J Clin Densitom. 12:292-8.

30. Berro AJ, Al Rassy N, Ahmaidi S, et al. 2018 Physical performance variables and bone parameters in a group of young overweight and obese women. J Clin Densitom. In press.

31. World Health Organization. 2000 Obesity: Preventing and managing the global epidemic. WHO technical report series, Geneva.

32. Beck TJ, Ruff CB, Warden KE, LeBoff MS, Cauley JA, Chen Z. 1990 Predicting femoral neck strength from bone mineral data. A structural approach. Invest Radiol. 25(1):6-18.

33. Silva BC, Broy SB, Boutroy S, et al. 2015 Fracture risk prediction by non-BMD DXA measures: the 2015 ISCD Official Positions Part 2: trabecular bone score. J Clin Densitom. 18(3):309-330. 
34. Harvey NC, Glüer CC, Binkley N, et al. 2015 Trabecular bone score (TBS) as a new complementary approach for osteoporosis evaluation in clinical practice. Bone. 78:216-224.

35. El Hage R, Bachour F, Sebaalt A, et al. 2014 The influence of weight status on radial bone mineral density in Lebanese women. Calcif Tissue Int. 94(4):465-467.

36. El Hage R, Bachour F, Khairallah W, et al. 2014 The influence of obesity and overweight on hip bone mineral density in Lebanese women. J Clin Densitom. 17(1):216-217.

37. Zakhem E, Ayoub MI, Zunquin G, et al. 2015 Physical performance and trabecular bone score in a group of young Lebanese women. J Clin Densitom. 18:271-272.

38. Harman EA, Rosenstein MT, Frykman PN, Rosenstein RM, Kraemer WJ. 1991 Estimation of human power output from vertical jump. JASS. 5(3):116-120.

39. El Khoury C, Pinti A, Lespessailles E, et al. 2018 Physical performance variables and bone mineral density in a group of young overweight and obese men. J Clin Densitom. 21(1):4147.

40. Zakhem E, El Khoury G, Feghaly L, et al. 2016 Performance physique et densité minérale osseuse chez de jeunes adultes libanais. J Med Liban. 64(4):193-199.

41. Janicka A, Wren TA, Sanchez MM, et al. 2007 Fat mass is not beneficial to bone in adolescents and young adults. J Clin Endocrinol Metab. 92(1):143-147.

42. Gilsanz V, Chalfant J, Mo AO, Lee DC, Dorey FJ, Mittelman SD. 2009 Reciprocal relations of subcutaneous and visceral fat to bone structure and strength. JCEM. 94:3387-3393.

43. Choi HS, Kim KJ, Kim KM, et al. 2010 Relationship between visceral adiposity and bone mineral density in Korean adults. Calcified Tissue International. 87:218-225. 
44. Yamaguchi T, Kanazawa I, Yamamoto M, et al. 2009 Associations between components of the metabolic syndrome versus bone mineral density and vertebral fractures in patients with type 2 diabetes. Bone. 45:174-179.

45. El Khoury G, Zouhal H, Cabagno G, et al. 2017 Bone variables in active overweight/obese men and sedentary overweight/obese men. J Clin Densitom. 20(2):239-246.

46. El Hage R, Jacob C, Moussa E, et al. 2009 Effects of 12 weeks of endurance training on bone mineral content and bone mineral density in obese, overweight and normal weight adolescent girls. Sci Sports. 24(3-4):210-213.

47. El Hage R. 2012 Geometric indices of hip bone strength in obese, overweight, and normal-weight adolescent boys. Osteoporos Int. 23(5):1593-1600.

48. El Hage R. 2013 Geometric indices of hip bone strength in young female football players. J Musculoskelet Neuronal Interact. 13(2):206-212.

49. Madeira E, Mafort TT, Madeira M, et al. 2014 Lean mass as a predictor of bone density and microarchitecture in adult obese individuals with metablic syndrome. Bone. 59:89-92.

50. Petit MA, Beck TJ, Hughes JM, et al. 2008 Proximal femur mechanical adaptation to weight gain in late adolescence: a six-year longitudinal study. J Bone Miner Res. 23:180-188.

51. MacKelvie KJ, McKay HA, Petit MA, et al. 2002 Bone mineral response to a 7-month randomized controlled, school-based jumping intervention in 121 prepubertal boys: associations with ethnicity and body mass index. J Bone Miner Res. 17(5):834-844.

52. Bonjour JP, Chevalley T, Rizzoli R, et al. 2007 Gene environment interactions in the skeletal response to nutrition and exercise during growth. Med Sport Sci. 51:64-80. 
53. El Hage Z, Theunynck D, Jacob C, et al. 2011 Hip bone strength indices in overweight and control adolescent boys. J Bone Miner Metab. 29(6):691-698.

54. El Hage Z, Theunynck D, Jacob C, et al. 2013 Bone mineral content and density in obese, overweight and normal weight adolescent boys. J Med Liban. 61(3):148-154.

55. El Hage R, Courteix D, Benhamou CL, Jacob C, Jaffré C. 2009 Relative importance of lean and fat mass on bone mineral density in a group of adolescent girls and boys. Eur J Appl Physiol. 105(5):759-764.

56. Beck TJ. 2003 Measuring the structural strength of bones with dual-energy X-ray absorptiometry: principles, technical limitations, and future possibilities. Osteoporos Int. 14(Suppl 5):S81-S88.

57. Beck TJ. 2007 Extending DXA beyond bone mineral density: understanding hip structure analysis. Curr Osteoporos Rep. 5(2):49-55. 
Table 1: Physical Characteristics of the Study Population

\begin{tabular}{|c|c|c|}
\hline Characteristics & Men $(n=53)$ & Women $(n=148)$ \\
\hline & Mean \pm SD & Mean \pm SD \\
\hline Age (yr) & $24.3 \pm 4.9$ & $24.1 \pm 3.9$ \\
\hline Weight (kg) & $84.9 \pm 20.0 * * *$ & \\
\hline Height (m) & $1.73 \pm 0.08 * * *$ & \\
\hline BMI $\left(\mathrm{kg} / \mathrm{m}^{2}\right)$ & $27.9 \pm 5.3^{* *}$ & $25.3 \pm 4.8$ \\
\hline Lean Mass (kg) & $55.306 \pm 12.02 * * *$ & $39.751 \pm 8.646$ \\
\hline Fat Mass (kg) & $26.646 \pm 14.881$ & $25.191 \pm 8.638$ \\
\hline Fat Mass $\%$ & $27.4 \pm 9.4 * * *$ & $36.4 \pm 6.9$ \\
\hline WB BMC (g) & $919 \pm 394 * * *$ & $2309 \pm 397$ \\
\hline WB BMD $\left(\mathrm{g} / \mathrm{cm}^{2}\right)$ & $\pm 0.097 *$ & $1.101 \pm 0.106$ \\
\hline L1-L4 BMC (g) & $70.4 \pm 12.3^{* * *}$ & $60.7 \pm 11.9$ \\
\hline L1-L4 B & $1.170 \pm 0.126$ & $1.152 \pm 0.131$ \\
\hline L1-L4 TBS & $1.409 \pm 0.106$ & $1.427 \pm 0.106$ \\
\hline TH BMC (g) & $39.1 \pm 6.4^{* * *}$ & $29.5 \pm 6.1$ \\
\hline TH BMD $\left(\mathrm{g} / \mathrm{cm}^{2}\right)$ & $1.106 \pm 0.132 * * *$ & $0.988 \pm 0.125$ \\
\hline FN BMC (g) & $5.90 \pm 0.88 * * *$ & $4.62 \pm 0.99$ \\
\hline
\end{tabular}




\begin{tabular}{|l|c|c|}
\hline FN BMD $\left(\mathrm{g} / \mathrm{cm}^{2}\right)$ & $1.104 \pm 0.146^{* * *}$ & $0.973 \pm 0.139$ \\
\hline FN CSA $\left(\mathrm{mm}^{2}\right)$ & $186.6 \pm 27.0 * * *$ & $150.2 \pm 28.3$ \\
\hline FN CSMI $\left(\mathrm{mm}^{2}\right)^{2}$ & $16040 \pm 3675^{* * *}$ & $10485 \pm 3863$ \\
\hline FN Z $\left(\mathrm{mm}^{3}\right)$ & $898 \pm 207^{* * *}$ & $635 \pm 194$ \\
\hline BR & $5.73 \pm 2.35$ & $6.604 \pm 3.142$ \\
\hline FN SI & $1.592 \pm 0.468$ & $1.633 \pm 0.433$ \\
\hline Vertical jump (m) & & \\
\hline Maximum power (w) & $1011 \pm 401^{* * *}$ & $5.167 \pm 0.085$ \\
& & \\
\hline
\end{tabular}

$\mathrm{BMI}$, body mass index; $\mathrm{WB}$, whole body; $\mathrm{BMC}$, bone mineral content; $\mathrm{BMD}$, bone mineral density; TBS, trabecular bone score; TH, total hip; FN, femoral neck; CSA, cross-sectional area; CSMI, cross-sectional moment of inertia; Z, section modulus; BR, buckling ratio; SI, strength index; SD, standard deviation. ${ }^{*} p<0.05 ;{ }^{* *} p<0.01 ; * * * p<0.001$. 
Table 2: Correlations Between Clinical Characteristics and Bone Variables in Young Men

\begin{tabular}{|c|c|c|c|c|c|c|c|c|c|c|c|c|c|c|}
\hline$N=53$ & $\begin{array}{l}\text { WB } \\
\text { BMC } \\
\text { (g) }\end{array}$ & $\begin{array}{c}\text { WB } \\
\text { BMD } \\
\left(\mathrm{g} / \mathrm{cm}^{2}\right)\end{array}$ & $\begin{array}{l}\text { L1-L4 } \\
\text { BMC } \\
\text { (g) }\end{array}$ & $\begin{array}{c}\text { L1-L4 } \\
\text { BMD } \\
\left(\mathrm{g} / \mathrm{cm}^{2}\right)\end{array}$ & $\begin{array}{c}\text { L1-L4 } \\
\text { TBS }\end{array}$ & $\begin{array}{r}\text { TH } \\
\text { BMC } \\
\text { (g) }\end{array}$ & $\begin{array}{c}\text { TH } \\
\text { BMD } \\
\left(\mathrm{g} / \mathrm{cm}^{2}\right)\end{array}$ & $\begin{array}{c}\text { FN } \\
\text { BMC } \\
\text { (g) }\end{array}$ & $\begin{array}{c}\text { FN } \\
\text { BMD } \\
\left(\mathrm{g} / \mathrm{cm}^{2}\right)\end{array}$ & $\begin{array}{c}\mathrm{FN} \\
\mathrm{CSA} \\
\left(\mathrm{mm}^{2}\right)\end{array}$ & $\left(\mathrm{mm}^{2}\right)^{2}$ & $\begin{array}{c}\mathrm{FN} \mathrm{Z} \\
\left(\mathrm{mm}^{3}\right)\end{array}$ & BR & FN SI \\
\hline $\begin{array}{l}\text { Age } \\
\text { (yr) }\end{array}$ & -0.03 & -0.10 & 0.01 & -0.12 & -0.26 & -0.22 & -0.27 & -0.28 & -0.28 & $\begin{array}{c}-0.28 \\
*\end{array}$ & -0.16 & -0.14 & $\begin{array}{c}-0.44 \\
*\end{array}$ & -0.12 \\
\hline $\begin{array}{c}\text { Weight } \\
\text { (kg) }\end{array}$ & $\begin{array}{l}0.63 \\
* * *\end{array}$ & $\begin{array}{c}0.41 \\
* *\end{array}$ & $\begin{array}{c}0.31 \\
*\end{array}$ & 0.12 & -0.25 & 0.49 & & & 0.19 & $\begin{array}{c}0.34 \\
*\end{array}$ & $\begin{array}{c}0.42 \\
* *\end{array}$ & $\begin{array}{c}0.45 \\
*\end{array}$ & 0.24 & $\begin{array}{l}-0.57 \\
* * *\end{array}$ \\
\hline $\begin{array}{l}\text { Height } \\
\text { (m) }\end{array}$ & $\begin{array}{l}0.77 \\
* * *\end{array}$ & $\begin{array}{c}0.40 \\
* *\end{array}$ & $* * *$ & 0.18 & & & 0.26 & $\begin{array}{l}0.45 \\
* * *\end{array}$ & 0.24 & $\begin{array}{l}0.49 \\
* * *\end{array}$ & $\begin{array}{l}0.60 \\
* * *\end{array}$ & $\begin{array}{c}0.54 \\
* *\end{array}$ & -0.18 & -0.12 \\
\hline $\begin{array}{c}\text { BMI } \\
\left(\mathrm{kg} / \mathrm{m}^{2}\right)\end{array}$ & $\begin{array}{c}0.37 \\
* *\end{array}$ & 0.30 & & & -0.17 & 0.29 & 0.16 & 0.16 & 0.12 & 0.17 & 0.21 & 0.31 & $\begin{array}{c}0.43 \\
*\end{array}$ & $\begin{array}{c}-0.62 \\
* * *\end{array}$ \\
\hline
\end{tabular}




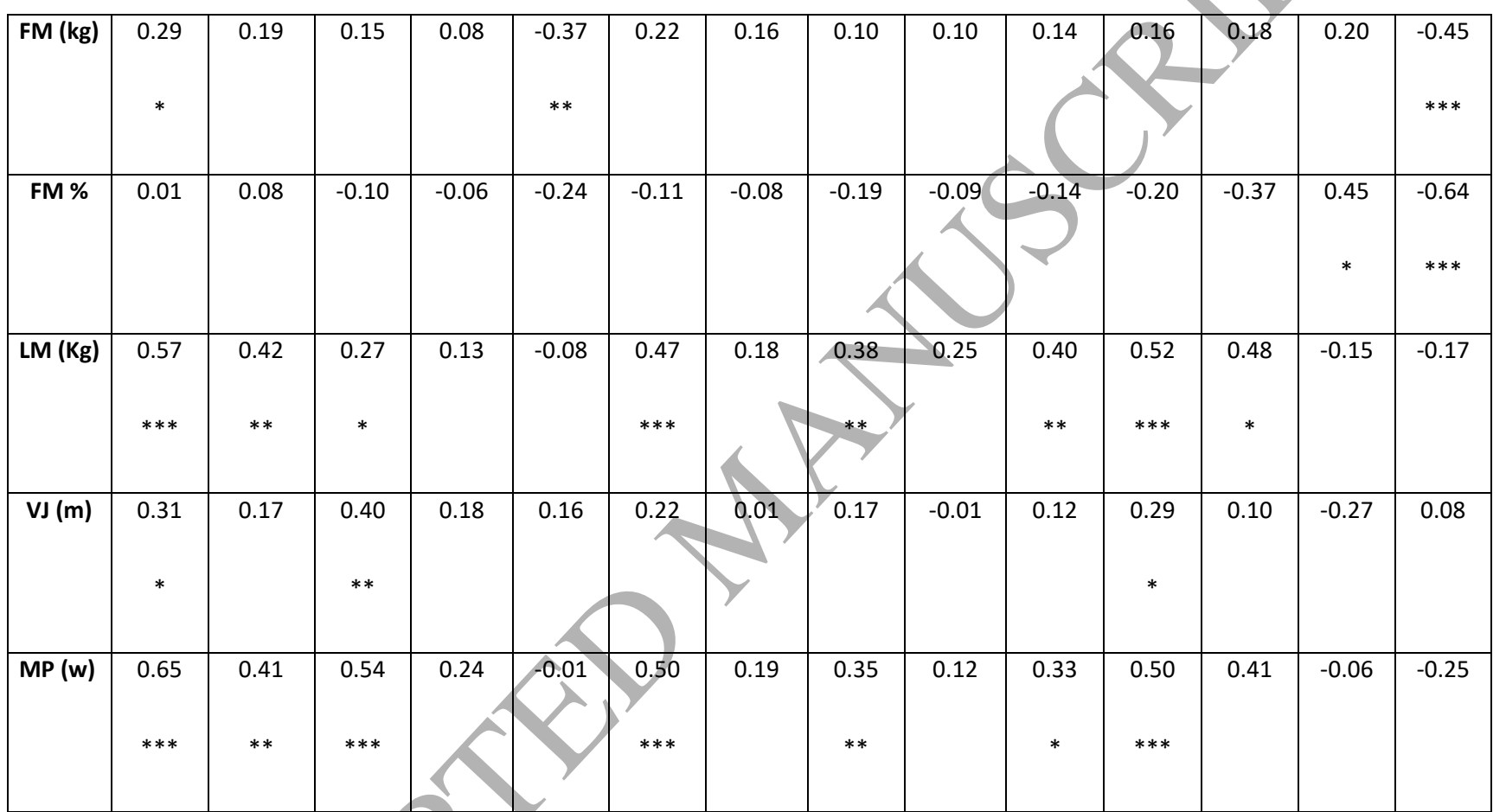

BMI, body mass index; FM, fat mass; LM, lean mass; VJ, vertical jump; MP, maximum power; WB, whole body; BMC, bone mineral content; $\mathrm{BMD}$, bone mineral density; TBS, trabecular bone score; TH, total hip; FN, femoral neck; CSA, cross-sectional area; CSMI, cross-sectional moment of inertia; Z, section modulus; BR, buckling ratio; SI, strength index. ${ }^{*} p<0.05 .{ }^{* *} p<0.01 .{ }^{* * *} p<0.001$. 
Table 3: Correlations Between Clinical Characteristics and Bone Variables in Young Women

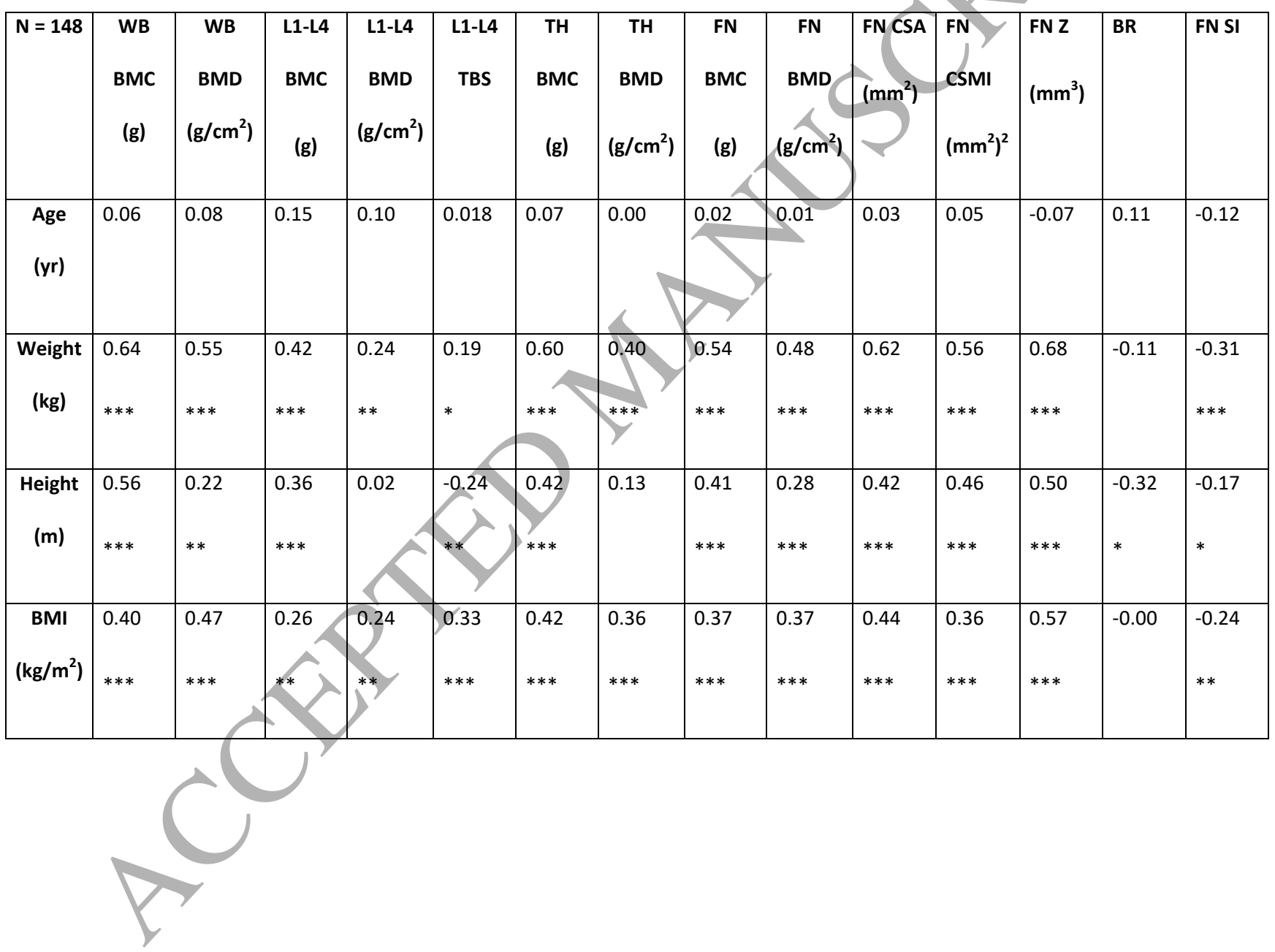




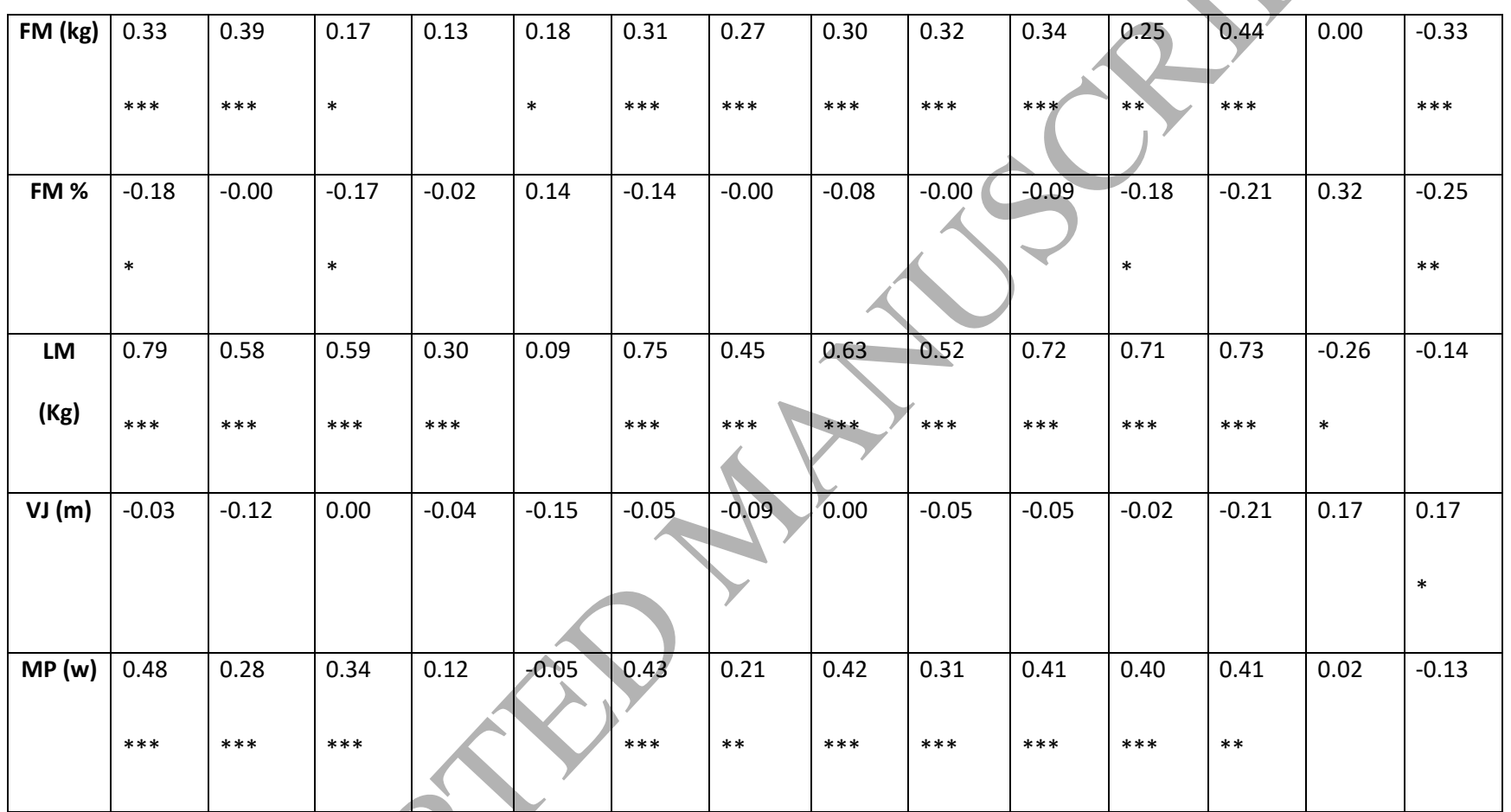

BMI, body mass index; FM, fat mass; LM, lean mass; VJ, vertical jump; MP, maximum power; WB, whole body; BMC, bone mineral content; BMD, bone mineral density; TBS, trabecular bone score; TH, total hip; FN, femoral neck; CSA, cross-sectional area; CSMI, cross-sectional moment of inertia; $Z$, section modulus; BR, buckling ratio; SI, strength index. ${ }^{*} p<0.05$. $* * p<0.01$. $* * * p<0.001$. 
Table 4: Multiple Linear Regressions in Men

\begin{tabular}{|c|c|c|c|}
\hline $\operatorname{Men}(n=53)$ & Coefficient \pm SE & $t$ value & $p$ value \\
\hline \multicolumn{4}{|c|}{$\begin{array}{l}\text { Dependent variable: WB } \\
\text { BMC }\left(R^{2}=0.711\right)\end{array}$} \\
\hline Constant & $1857.263 \pm 184.878$ & 10.046 & \\
\hline Maximum Power (w) & $0.481 \pm 0.115$ & 4.173 & $<0.001$ \\
\hline Lean Mass (kg) & $10.399 \pm 3.854$ & & 0.009 \\
\hline $\begin{array}{l}\text { Dependent variable: } \\
\text { BMD }\left(R^{2}=0.481\right)\end{array}$ & & & \\
\hline Constant & $1.016 \pm 0.0567$ & 17.939 & $<0.001$ \\
\hline Maximum Power (w) & $0.0000658 \pm 0.0000354$ & 1.861 & 0.069 \\
\hline Lean Mass (kg) & $0.00224 \pm 0.00118$ & 1.897 & 0.064 \\
\hline \multicolumn{4}{|c|}{ Dependent variable: L1-L4 } \\
\hline Constant & $54.162 \pm 6.947$ & 7.797 & $<0.001$ \\
\hline Maximum Power (w) & $0.017 \pm 0.00435$ & 3.901 & $<0.001$ \\
\hline Lean Mass (kg) & $-0.0178 \pm 0.145$ & -0.124 & 0.902 \\
\hline
\end{tabular}




\begin{tabular}{|c|c|c|c|}
\hline $\begin{array}{l}\text { Dependent variable: L1-L4 } \\
\text { BMD }\left(R^{2}=0.248\right)\end{array}$ & & & \\
\hline Constant & $1.087 \pm 0.081$ & 13.416 & $<0.001$ \\
\hline Maximum Power (w) & $0.0000759 \pm 0.0000505$ & 1.502 & \\
\hline Lean Mass ( $\mathrm{kg}$ ) & $0.000112 \pm 0.00169$ & 0.0664 & \\
\hline \multicolumn{4}{|l|}{$\begin{array}{l}\text { Dependent variable: L1-L4 } \\
\text { TBS }\left(R^{2}=0.0924\right)\end{array}$} \\
\hline Constant & $1.449 \pm 0.0705$ & 20.557 & $<0.001$ \\
\hline Maximum Power (w) & $0.0000124 \pm 0.000044$ & 0.283 & 0.779 \\
\hline Lean Mass ( $\mathrm{kg}$ ) & $-0.000958 \pm 0.00147$ & -0.652 & 0.517 \\
\hline $\begin{array}{l}\text { Dependent variable: } \mathrm{TH} \\
\mathrm{BMC}\left(R^{2}=0.565\right)\end{array}$ & & & \\
\hline Constant & $24.629 \pm 3.569$ & 6.902 & $<0.001$ \\
\hline Maximum Power (w) & $0.00572 \pm 0.00223$ & 2.568 & 0.013 \\
\hline Lean Mass (kg) & $0.158 \pm 0.0744$ & 2.119 & 0.039 \\
\hline \multicolumn{4}{|l|}{$\begin{array}{l}\text { Dependent variable: } \mathrm{TH} \\
\mathrm{BMD}\left(R^{2}=0.220\right)\end{array}$} \\
\hline Constant & $0.99 \pm 0.0856$ & 11.563 & $<0.001$ \\
\hline
\end{tabular}




\begin{tabular}{|c|c|c|c|}
\hline Maximum Power (w) & $0.0000436 \pm 0.0000534$ & 0.816 & 0.418 \\
\hline Lean Mass (kg) & $0.0013 \pm 0.00178$ & 0.729 & 0.469 \\
\hline $\begin{array}{l}\text { Dependent variable: } \\
\text { BMC }\left(R^{2}=0.423\right)\end{array}$ & & & \\
\hline Constant & $4.319 \pm 0.533$ & 8.1 & \\
\hline Maximum Power (w) & $0.000451 \pm 0.000333$ & 1.356 & 0.181 \\
\hline Lean Mass ( $\mathrm{kg}$ ) & $0.0204 \pm 0.0111$ & & 0.073 \\
\hline $\begin{array}{l}\text { Dependent variable: } \\
\mathrm{BMD}\left(R^{2}=0.256\right)\end{array}$ & & & \\
\hline Constant & $0.933 \pm 0.094$ & 9.918 & $<0.001$ \\
\hline Maximum Power (w) & -0.00000433 & -0.0738 & 0.942 \\
\hline Lean Mass ( $\mathrm{kg}$ ) & $0.00318 \pm 0.00196$ & 1.625 & 0.111 \\
\hline \multicolumn{4}{|c|}{ Dependent variable: FN } \\
\hline Constant & $135.835 \pm 16.231$ & 8.369 & $<0.001$ \\
\hline Maximum Power (w) & $0.0116 \pm 0.0101$ & 1.143 & 0.258 \\
\hline Lean Mass (kg) & $0.708 \pm 0.338$ & 2.092 & 0.041 \\
\hline
\end{tabular}




\begin{tabular}{|c|c|c|c|}
\hline $\begin{array}{l}\text { Dependent variable: FN } \\
\text { CSMI }\left(R^{2}=0.592\right)\end{array}$ & & & \\
\hline Constant & $7049.766 \pm 1971.804$ & 3.575 & $<0.001$ \\
\hline Maximum Power (w) & $2.931 \pm 1.23$ & 2.382 & 0.02 \\
\hline Lean Mass (kg) & $108.954 \pm 41.103$ & 2.651 & \\
\hline $\begin{array}{l}\text { Dependent variable: } \mathrm{FN} \\
\left(R^{2}=0.550\right)\end{array}$ & & & \\
\hline Constant & $412.049 \pm 169.309$ & & 0.024 \\
\hline Maximum Power (w) & $0.176 \pm 0.123$ & 1.43 & 0.168 \\
\hline Lean Mass ( $\mathrm{kg}$ ) & $5.69 \pm$ & 1.949 & 0.065 \\
\hline $\begin{array}{l}\text { Dependent variable: } B R \\
=0.159)\end{array}$ & & & \\
\hline Constant & $7.166 \pm 2.265$ & 3.164 & 0.005 \\
\hline Maximum Power (w) & $-0.0000561 \pm 0.00165$ & -0.0341 & 0.973 \\
\hline Lean Mass (kg) & $-0.026 \pm 0.039$ & -0.666 & 0.513 \\
\hline $\begin{array}{l}\text { Dependent variable: } \mathrm{FN} \\
\left(R^{2}=0.258\right)\end{array}$ & & & \\
\hline Constant & $1.973 \pm 0.301$ & 6.558 & $<0.001$ \\
\hline
\end{tabular}




\begin{tabular}{|l|l|l|l|}
\hline Maximum Power $(\mathrm{w})$ & $-0.000263 \pm 0.000188$ & -1.401 & 0.168 \\
\hline Lean Mass (kg) & $-0.00207 \pm 0.00627$ & -0.33 & 0.743 \\
\hline
\end{tabular}

WB, whole body; $B M C$, bone mineral content; $B M D$, bone mineral density; TBS, trabecular bone score; TH, total hip; FN, femoral neck; CSA, cross-sectional area; CSMI, cross-sectional moment of inertia; Z, section modulus; BR, buckling ratio; SI, strength index. 
Table 5: Multiple Linear Regressions in Women

\begin{tabular}{|c|c|c|c|}
\hline Women $(n=148)$ & Coefficient $\pm \mathrm{SE}$ & $t$ value & $p$ value \\
\hline \multicolumn{4}{|c|}{ Dependent variable: WB } \\
\hline Constant & $834.234 \pm 96.659$ & 8.631 & \\
\hline Maximum Power (w) & $0.175 \pm 0.143$ & 1.228 & 0.222 \\
\hline Lean Mass ( $\mathrm{kg}$ ) & $34.61 \pm 2.763$ & & $<0.001$ \\
\hline $\begin{array}{l}\text { Dependent variable: } \\
\mathrm{BMD}\left(R^{2}=0.586\right)\end{array}$ & & & \\
\hline Constant & $0.823 \pm 0.0344$ & 23.94 & $<0.001$ \\
\hline Maximum Power (w) & $-0.0000345 \pm 0.0000508$ & -0.68 & 0.498 \\
\hline Lean Mass ( $\mathrm{kg}$ ) & $0.00751 \pm 0.000982$ & 7.643 & $<0.001$ \\
\hline \multicolumn{4}{|c|}{ Dependent variable: L1-L4 } \\
\hline Constant & $27.291 \pm 3.94$ & 6.927 & $<0.001$ \\
\hline Maximum Power (w) & $0.00341 \pm 0.00572$ & 0.596 & 0.552 \\
\hline Lean Mass (kg) & $0.797 \pm 0.111$ & 7.194 & $<0.001$ \\
\hline
\end{tabular}




\begin{tabular}{|c|c|c|c|}
\hline $\begin{array}{l}\text { Dependent variable: L1-L4 } \\
\text { BMD }\left(R^{2}=0.309\right)\end{array}$ & & & \\
\hline Constant & $0.975 \pm 0.05$ & 19.505 & $<0.001$ \\
\hline Maximum Power (w) & $-0.0000464 \pm 0.0000739$ & -0.628 & \\
\hline Lean Mass ( $\mathrm{kg}$ ) & $0.00512 \pm 0.00143$ & 3.582 & $<0.0$ \\
\hline \multicolumn{4}{|l|}{$\begin{array}{l}\text { Dependent variable: L1-L4 } \\
\text { TBS }\left(R^{2}=0.150\right)\end{array}$} \\
\hline Constant & $1.396 \pm 0.0421$ & & $<0.001$ \\
\hline Maximum Power (w) & $-0.0000901 \pm 0.0000622$ & -1.449 & 0.15 \\
\hline Lean Mass ( $\mathrm{kg}$ ) & $0.00207 \pm 0.0012$ & 1.717 & 0.088 \\
\hline $\begin{array}{l}\text { Dependent variable: } \mathrm{TH} \\
\mathrm{BMC}\left(R^{2}=0.755\right)\end{array}$ & & & \\
\hline Constant & $8.122 \pm 1.612$ & 5.04 & $<0.001$ \\
\hline Maximum Power (w) & $0.00116 \pm 0.00238$ & 0.487 & 0.627 \\
\hline Lean Mass (kg) & $0.523 \pm 0.0461$ & 11.346 & $<0.001$ \\
\hline \multicolumn{4}{|l|}{$\begin{array}{l}\text { Dependent variable: } \mathrm{TH} \\
\mathrm{BMD}\left(R^{2}=0.451\right)\end{array}$} \\
\hline Constant & $0.734 \pm 0.0446$ & 16.44 & $<0.001$ \\
\hline
\end{tabular}




\begin{tabular}{|c|c|c|c|}
\hline Maximum Power (w) & $-0.0000297 \pm 0.000066$ & -0.45 & 0.654 \\
\hline Lean Mass (kg) & $0.00682 \pm 0.00128$ & 5.341 & $<0.001$ \\
\hline \multicolumn{4}{|c|}{$\begin{array}{l}\text { Dependent variable: } \mathrm{FN} \\
\mathrm{BMC}\left(R^{2}=0.642\right)\end{array}$} \\
\hline Constant & $1.621 \pm 0.305$ & 5.312 & $<0.001$ \\
\hline Maximum Power (w) & $0.000708 \pm 0.000451$ & 1.569 & 0.119 \\
\hline Lean Mass (kg) & $0.0654 \pm 0.00872$ & & $<0.001$ \\
\hline $\begin{array}{l}\text { Dependent variable: } \\
\operatorname{BMD}\left(R^{2}=0.526\right)\end{array}$ & & & \\
\hline Constant & $0.632 \pm 0.0475$ & 13.318 & $<0.001$ \\
\hline Maximum Power (w) & $0.0000294 \pm 0.0000702$ & 0.419 & 0.676 \\
\hline Lean Mass (kg) & $0.00815 \pm 0.00136$ & 6.011 & $<0.001$ \\
\hline \multicolumn{4}{|c|}{ Dependent variable: FN } \\
\hline Constant & $55.11 \pm 7.826$ & 7.042 & $<0.001$ \\
\hline Maximum Power (w) & $0.00516 \pm 0.0116$ & 0.446 & 0.656 \\
\hline Lean Mass (kg) & $2.319 \pm 0.224$ & 10.367 & $<0.001$ \\
\hline
\end{tabular}




\begin{tabular}{|c|c|c|c|}
\hline $\begin{array}{l}\text { Dependent variable: } \mathrm{FN} \\
\operatorname{CSMI}\left(R^{2}=0.716\right)\end{array}$ & & & \\
\hline Constant & $-2287.192 \pm 1080.394$ & -2.117 & 0.036 \\
\hline Maximum Power (w) & $0.356 \pm 1.597$ & 0.223 & \\
\hline Lean Mass ( $\mathrm{kg}$ ) & $316.221 \pm 30.882$ & 10.24 & $<0.00$ \\
\hline \multicolumn{4}{|l|}{$\begin{array}{l}\text { Dependent variable: } \mathrm{FN} \mathrm{Z} \\
\left(R^{2}=0.733\right)\end{array}$} \\
\hline Constant & $122.028 \pm 76.25$ & & 0.115 \\
\hline Maximum Power (w) & $-0.00768 \pm 0.128$ & -0.06 & 0.952 \\
\hline Lean Mass ( $\mathrm{kg}$ ) & $12.987 \pm 2.013$ & 6.452 & $<0.001$ \\
\hline $\begin{array}{l}\text { Dependent variable: } B R \\
=0.345)\end{array}$ & & & \\
\hline Constant & $8.314 \pm 1.698$ & 4.895 & $<0.001$ \\
\hline Maximum Power (w) & $0.00485 \pm 0.00285$ & 1.7 & 0.095 \\
\hline Lean Mass (kg) & $-0.119 \pm 0.0448$ & -2.664 & 0.01 \\
\hline \multicolumn{4}{|l|}{$\begin{array}{l}\text { Dependent variable: } \mathrm{FN} \mathrm{SI} \\
\left(R^{2}=0.158\right)\end{array}$} \\
\hline Constant & $1.946 \pm 0.171$ & 11.37 & $<0.001$ \\
\hline
\end{tabular}




\begin{tabular}{|l|l|l|l|}
\hline Maximum Power $(\mathrm{w})$ & $-0.00022 \pm 0.000253$ & -0.872 & 0.385 \\
\hline Lean Mass (kg) & $-0.00471 \pm 0.00489$ & -0.964 & 0.337 \\
\hline
\end{tabular}

WB, whole body; BMC, bone mineral content; BMD, bone mineral density; TBS, trabecular bone score; TH, total hip; FN, femoral neck; CSA, cross-sectional area; CSMI, cross-sectional moment of inertia; Z, section modulus; BR, buckling ratio; SI, strength index. 